\title{
LOCAL CLIMATE AFFECTS GROWTH AND GRAIN PRODUCTIVITY OF PRECISION HILL-DIRECT-SEEDED RICE IN SOUTH CHINA
}

\author{
MO, Z. W. ${ }^{1,2 \dagger}-$ PAN, S. G. ${ }^{1,2 \dagger}-$ ASHRAF, $\mathrm{U}^{1 \dagger}-$ KANU, A. S. ${ }^{1}-\mathrm{LI}, \mathrm{W}^{3}{ }^{3}-\mathrm{WANG}, \mathrm{Z} . \mathrm{M}^{4}{ }^{4}$ \\ DUAN, M. Y. ${ }^{1,2}-$ TIAN, H. ${ }^{1,2}-$ KARGBO, M. B. ${ }^{5}-$ TANG, X. R. $^{1,2^{*}}$ \\ ${ }^{I}$ Department of Crop Science and Technology, College of Agriculture, South China Agricultural \\ University, Guangzhou 510642, China \\ ${ }^{2}$ Scientific Observing and Experimental Station of Crop cultivation in South China, Ministry of \\ Agriculture. P. R. China \\ ${ }^{3}$ Crops Research Institute, Guangdong Academy of Agricultural Sciences, Guangzhou, \\ Guangdong 510640, China \\ ${ }^{4}$ College of Engineering, South China Agricultural University, Guangzhou 510642, China \\ ${ }^{5}$ Agricultural Education Department, Northern Polytechnic, Makeni, Sierra Leone \\ *Corresponding author \\ e-mail: tangxr@scau.edu.cn
}

tThese authors contributed equally to this work.

(Received 27 Jul 2016; Accepted $29^{\text {th }}$ Oct 2016)

\begin{abstract}
Temperature fluctuations at critical growth stages of rice may cause crop yield loss, shifts in crop growth periods as well as in sowing and harvesting times. Direct seeded rice has been proved as a the best alternative to transplanted rice and has been adopted successfully in many regions over the globe. This study was carried out to evaluate the productivity of rice sown under different environments with precision hill-direct-seeding method. Four rice varieties viz. Peizataifeng, Yuxiangyouzhan, Huahang 31 and Huayou 213 were sown in 6 different environments (E1-E6) by following split-plot design with four replications. Results showed that environments $(\mathrm{E})$, varieties $(\mathrm{V})$ and their interactions $(\mathrm{E} \times \mathrm{V})$ significantly $(\mathrm{p} \leq 0.01)$ affected seedling survival rate, grain yield and yield related traits like panicles $\mathrm{m}^{-2}$, spikelets panicle ${ }^{-1}(\mathrm{p} \leq 0.05)$, fully filled grain $\%, 1000$-grain weight, harvest index as well as daily dry matter and grain productivity. Differential varietal response under different environments depicted that all environments remained productive regarding rice growth and yield except environment 3 (E3) that caused grain yield reduction up to $45.86 \%$. The overall performance and yield response of rice varieties under different environments was recorded as: Huahang $31>$ Yuxiangyouzhan $>$ Peizataifeng $>$ Hиауои 213. Further, correlation analysis showed significant and positive relationships of rice grain yield with yield contributing factors $(r>0.47)$ except panicles $\mathrm{m}^{-2}$ and grains panicle ${ }^{-1}$. Hence, fluctuations in regional/local climatic conditions may cause shifts in sowing/planting times, poor stand establishment and seedlings survival rates that may lead to yield penalty in rice.
\end{abstract}

Keywords: environment, growth, rice cultivars, temperature fluctuations, yield

\section{Introduction}

Rice is one of the world's most important cereal and a major food for more than half of the global population (Farooq et al., 2011; Krishnan et al., 2011; Ashraf et al., 2014). 
In China, more than $65 \%$ population solely relies on rice that serves as staple food (Zhang et al., 2005; Mo et al., 2016a). So for maintaining food security in China and to save the world population from hunger, it is necessary to increase the rice productivity by adopting better management strategies (Fang and Cheng, 2009; Ashraf et al., 2015). In general, about 0.6 to $0.9 \%$ increase in rice production per annum is required to meet the consumption rate of increasing population worldwide (Carriger and Vallee, 2007). On the other hand an increase of crop productivity per unit of land area is needed due to the effects of urbanization and industrialization on agricultural lands (Takai et al., 2006).

Climate change is one of the external factors that affect crop productivity worldwide, and may have significant impacts on growth and yield formation of rice. Predictions about climate change through general circulation models warrant an increase in global temperature of $4{ }^{\circ} \mathrm{C}$ by the end of $21^{\text {st }}$ century (IPCC, 2007) which confirms that future rice production will be in warmer climate.

Thus, adjustment of crop planting dates is an important strategy to avoid the effects of environmental severities in order to maintain crop growth and productivity (Sacks et al., 2010; Yao et al., 2011). Sowing dates affect rice growth duration, thus affecting rice response to light, temperature and other environmental factors (Wang et al., 2001a; Wang et al., 2001b; Yao et al., 2012; Ehsanullah et al., 2014). Low temperature in spring is the main factor that affects sowing date of direct seeding rice, for example, sowing too early may result in low temperature stress, whilst late sowing may face difficulty in the coordination of temperature and light growth period and ultimately the productivity of rice (Yi et al., 2010). The suitable temperature indices to get higher paddy yields during early-season rice in Guangdong province (China) are as follows: whole growth period is $23-24{ }^{\circ} \mathrm{C}$, whereas from germination $\rightarrow$ tillering $\rightarrow$ booting $\rightarrow$ heading $\rightarrow$ physiological maturity are $18-21{ }^{\circ} \mathrm{C}, 21-25^{\circ} \mathrm{C}, 24-28{ }^{\circ} \mathrm{C}$ and $27-30{ }^{\circ} \mathrm{C}$, respectively (Wang et al., 2012). It has also been reported that rice should be sown earlier in Guangdong early-season rice cropping systems than their normal sowing (most probably in early March) in the fields due to the variable rainfall pattern and temperature fluctuations caused by a special climatic character of this region called "Dragon Boat Water" (Chen et al., 2006; Chen et al., 2010; Huang et al., 2011; Wang, Chen and Huang, 2011; Li et al., 2016).

Precision hill-direct-seeding of rice is a new planting technique developed by Luo et al. (2007) which has been used in China and some other countries in Asia (Kargbo et al., 2016). It showed advantages when compared to manual transplanting of rice nursery in the field and/or manual direct seeding (Luo et al., 2008; Tang et al., 2009). Moreover, precision hill-direct-seeding of rice requires optimal climatic conditions in the field, especially suitable temperature. In the best of our knowledge, to date, no experimental proof has yet been reported on the effects of different temperature regimes on seedling survival rate, growth and yield of precision hill-direct-seeded rice in the agro-climatic conditions of South China. Therefore, we have conducted a field experiment with four popularized rice cultivars sown under six different environments to study their effects on rice seedling survival rate, yield and yield components of precision hill-direct-seeded rice under local climatic conditions of the Guangdong province of South China where 
temperature fluctuations (low at early seedling establishment phase and high at flowering and grain filling stage) limits rice growth and productivity. The main objective of this study was to ascertain the impacts of changes in the local climatic conditions on the performance and yield formation of rice under field conditions.

\section{Materials and methods}

The field experiment was conducted at Experimental Research Farm, College of Agriculture, South China Agricultural University, Guangzhou $\left(23^{\circ} 09^{\prime} \mathrm{N}, 113^{\circ} 22^{\prime} \mathrm{E}\right.$ and $11 \mathrm{~m}$ above the sea level), Guangdong Province, P. R. China, during 2011. The experimental soil was sandy loam soil with following properties: soil $\mathrm{pH}=5.44$; organic matter $=19.65 \mathrm{~g} \mathrm{~kg}^{-1}$, total nitrogen $=0.97 \mathrm{~g} \mathrm{~kg}^{-1}$, available phosphorus $=31.74 \mathrm{mg} \mathrm{kg}^{-1}$, available potassium $=189.48 \mathrm{mg} \mathrm{kg}^{-1}$. This region has a humid subtropical monsoonal climate with warm winters and hot summers with an annual average temperature range lies between 21 to $29{ }^{\circ} \mathrm{C}$ (Mo et al., 2016b). Four popularized rice cultivars of this region i.e., Peizataifeng, Yuxiangyouzhan, Huahang 31 and Huayou 213 with 125-130 days of growth were obtained from College of Agriculture, South China Agricultural University Guagzhou, China. Among these cultivars, Peizataifeng and Huayou 213 were hybrid rice, whereas Yuxiangyouzhan and Huahang 31 were inbred rice.

Field preparation and crop management practices were followed according to the standard practices for this region (Tang et al., 2008). Before sowing, field was fully irrigated and then cultivated with tractor-mounted cultivator thrice, and two days later raked with laser land leveling machine. Seeds of all four rice cultivars were sown on 6 different dates (Table 1) using a precision hill-direct-seeding machine (2BD-10) at spacing of $(35 \mathrm{~cm}+15 \mathrm{~cm}) \times 14 \mathrm{~cm}$ with a seed rate of $15 \mathrm{~kg} \mathrm{ha}^{-1}$ in the well prepared land by following split-plot design with four replications. The meteorological data regarding temperature range and relative humidity during the whole rice growing season has been shown in Figure 1. 'Super rice special fertilizer' $1200 \mathrm{~kg} \mathrm{ha}^{-1}\left(\mathrm{~N} 12.5 \%, \mathrm{P}_{2} \mathrm{O}_{5}\right.$ $6.0 \%, \mathrm{~K}_{2} \mathrm{O} 10.0 \%$, organic matter $15.0 \%$ ) was applied 25 days after sowing. Mature crop was harvested on $10^{\text {th }}$ and $15^{\text {th }}$ July to record paddy yield and harvest index. Standard agronomic practices were followed with respect to irrigation, pest management, and weed control as recommended by the Guangdong Province, South China.

Table 1. Development of four rice cultivars as affected by a wide range of environmental conditions

\begin{tabular}{|c|c|c|c|c|c|}
\hline Environments & Sowing dates & $\begin{array}{l}\text { Dates of } 50 \% \\
\text { flowering }\end{array}$ & Days to harvest & $\begin{array}{l}\text { Mean max./min./ } \\
\text { Avg. temperature } \\
\left({ }^{\circ} \mathrm{C}\right)^{\text {a }}\end{array}$ & $\begin{array}{l}\text { Mean max./min./ } \\
\text { Avg. temperature } \\
\left({ }^{\circ} \mathrm{C}\right) \text { b }\end{array}$ \\
\hline E1 & 24-Feb & 2-Jun & 137 & $25.7 / 15.3 / 18.9$ & $33.2 / 23.7 / 27.9$ \\
\hline E2 & 1-Mar & 6-Jun & 132 & $22.0 / 13.4 / 16.9$ & $33.5 / 25.6 / 28.9$ \\
\hline E3 & 5-Mar & 9-Jun & 132 & $17.7 / 12.9 / 14.8$ & $32.8 / 25.8 / 28.7$ \\
\hline E4 & 10-Mar & 11-Jun & 127 & $22.5 / 13.4 / 17.0$ & $32.6 / 25.5 / 28.5$ \\
\hline E5 & 15-Mar & 12-Jun & 122 & $17.4 / 11.9 / 14.2$ & $32.3 / 25.5 / 28.3$ \\
\hline E6 & 20-Mar & 12-Jun & 117 & $20.3 / 13.9 / 16.3$ & $32.3 / 25.5 / 28.3$ \\
\hline
\end{tabular}




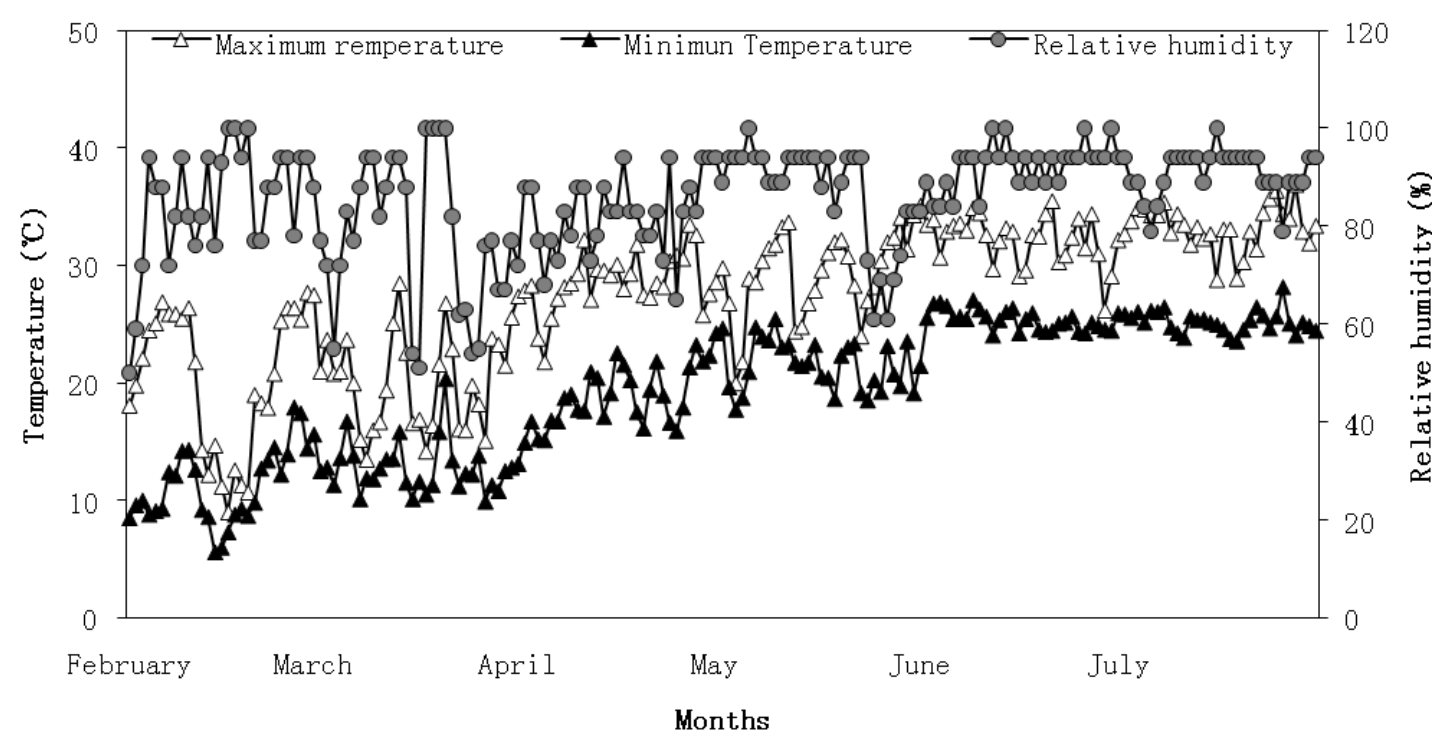

Figure 1. Daily maximum and minimum temperature $\left({ }^{\circ} \mathrm{C}\right)$ and relative humidity $(\%)$ during the course of study

Seed number were counted immediately from a randomly selected unit area $\left(1 \mathrm{~m}^{2}\right)$ at four different locations in each plot after sowing and recorded by marking each location; the survival seedling number was counted at each marked location at the four leaf stage to calculate the seedling survival rate by following formula: (survived seedlings / total rice seedlings) $\times 100$.

At maturity, four hills were uprooted randomly, oven-dried at $70{ }^{\circ} \mathrm{C}$ till constant weight to determine of rice dry biomass. Panicle numbers were counted from a randomly selected unit area $\left(1 \mathrm{~m}^{2}\right)$ at four different locations in each plot then averaged. Five hills were randomly selected from each plot to calculate total spikelets per panicle, grains per panicle and fully filled grain percentage. Five samples of thousand grains were taken randomly from each seed lot, weighed and averaged to record 1000-grain weight. One unit area $\left(1 \mathrm{~m}^{2}\right)$ of plants was harvested, threshed manually, sun dried, weighed and then adjusted to $14 \%$ moisture content to recorded grain yield.

Harvest index $(\mathrm{HI})$ was calculated as: (grain yield/biological yield) $\times 100$. Daily grain and dry matter productivity was calculated as the ratio between grain yield and dry matter accumulation at maturity to whole crop growth period and expressed in $\mathrm{kg}$ grain per hectare per day and $\mathrm{kg}$ dry weight per hectare per day $\left(\mathrm{kg} \mathrm{ha}^{-1} \mathrm{~d}^{-1}\right)$, respectively.

A split plot design with a plot size of $30 \mathrm{~m}^{2}$ was followed in which sowing dates and cultivars were randomized in main and subplots, respectively with four replications. Statistical analyses were performed using analysis of variance (ANOVA) by using Statistix 8 (Analytical software, Tallahassee, FL, USA). The differences amongst treatments were separated using least significant difference at the 5\% probability level. Figures were generated by using Microsoft Excel 2007. 


\section{Results}

After seed sowing, the highest values for mean maximum temperature were recorded in E1 while lowest values for mean maximum, minimum and average temperatures were recorded in E5 environment (Table 1). Days to 2-leaves stage in rice seedlings for E2 was exposed to temperatures less than $12{ }^{\circ} \mathrm{C}$ (around March 15) (Fig. 1; Table 1). Days to $50 \%$ flowering were shorter with late sowing (E5 and E6) than with early sowing (Table 1). Besides, days to harvest were shorter with late sowing than with early sowing, excluding a similar growth period in E2 and E3. The environment from E2 to E3, i.e., from March 2 to March 5 sowing seems to be the environment period that separated the six environments into the two ranges of environments. The mean maximum, minimum and average temperature of $50 \%$ flowering were in the range of 32.3-33.5 ${ }^{\circ} \mathrm{C}, 23.7-25.8^{\circ} \mathrm{C}$ and $27.9-28.9^{\circ} \mathrm{C}$, respectively. However, high temperatures $\left(\sim 35{ }^{\circ} \mathrm{C}\right)$ were observed in E3 (June 9) environment (Fig.1). Grain yield was significantly different for environments, variety their interaction $(\mathrm{E} \times \mathrm{V})($ Table 2). Among six different environments, E6 on average produced the highest grain yield, with E1-E5 affected by cooler temperature during seedling stage, and/or higher temperature during flowering and/or grain filling stage, resulting in significantly lower grain yields. For rice varieties, maximum and minimum grain yield was obtained for Huahang 31 $\left(6.75 \mathrm{t} \mathrm{ha}^{-1}\right.$ ) and Huayou 213 (4.75 $\left.\mathrm{t} \mathrm{ha}^{-1}\right)$, respectively (Fig. 3a).

Table 2. Effect of growing environment on grain yield, yield related traits, seedling survival rate and productivity of rice among varieties in terms of $F$-value

\begin{tabular}{llll}
\cline { 2 - 4 } Traits measured & Environment $(\mathbf{E})$ & Variety $(\mathbf{V})$ & $\mathbf{E} \times \mathbf{V}$ \\
\hline Grain yield & $2457.78^{* *}$ & $138.86^{* *}$ & $16.13^{* *}$ \\
Panicle number per $\mathrm{m}^{2}$ & $6.15^{* *}$ & $9.45^{* *}$ & $3.11^{* *}$ \\
Number of spikelets per panicle & $3.22^{*}$ & $14.27^{* *}$ & $2.85^{* *}$ \\
Fully filled grain percentage & $26.36^{* *}$ & $15.28^{* *}$ & $2.82^{* *}$ \\
1000-grain weight & $437.26^{* *}$ & $242.52^{* *}$ & $92.19^{* *}$ \\
Seedling survival rate & $82.51^{* *}$ & $8.99^{* *}$ & $12.72^{* *}$ \\
Daily dry matter productivity & $48.89^{* *}$ & $6.02^{* *}$ & $5.28^{* *}$ \\
Daily grain productivity & $3673.68^{* *}$ & $137.33^{* *}$ & $16.56^{* *}$ \\
Harvest index & $4.67^{* *}$ & $25.50^{* *}$ & $8.75^{* *}$ \\
\hline
\end{tabular}

Date with no asterisk were non-significant, $*$ and $* *$ mean significance at the 0.05 and 0.01 probability level, respectively

Yield related traits, seedling survival rate and productivity of rice varied significantly among varieties, environment, and $\mathrm{E} \times \mathrm{V}$ interactions (Table 2). Overall, maximum temperature had significant and positive effects on all yield related traits, seedling survival rate and productivity of rice except for number of grains per panicle and harvest index. Across environmental analysis revealed that low seedling survival rate in E2 and E3 (due to low temperature at this stage, especially at 2 leaf stage) than other environments led to reduced panicle number per $\mathrm{m}^{2}$ (Fig. 1, $2 c$ and $3 a$ ). Moreover, the 
maximum $(76.13 \%)$ and the minimum $(31.33 \%)$ seedling survival rate were recorded at E5 and E1, respectively (Fig. 3a). Grain filling percentage was affected by high temperature during E2-E4, which resulted in significant reduction in grain filling \% than other environments (Table 1, Fig. 2b). On average, E6 exhibited the highest daily grain and dry matter productivity (62.80 and $151.05 \mathrm{~kg} \mathrm{ha}^{-1} \mathrm{~d}^{-1}$, respectively) than other environments, while E3 was observed to decline in grain and dry matter productivity by 30.14 and $86.68 \mathrm{~kg} \mathrm{ha}^{-1} \mathrm{~d}^{-1}$, respectively. Furthermore, values for daily grain (37.47 to $53.02 \mathrm{~kg} \mathrm{ha}^{-1} \mathrm{~d}^{-1}$ ) and dry matter (109.23 to $119.86 \mathrm{~kg} \mathrm{ha}^{-1} \mathrm{~d}^{-1}$ ) were recorded in both inbred and hybrid rice cultivars (Fig. $3 b$ and d). Further, Huahang 31 and Yuxiangyouzha produced higher grain yield while substantial decrease in grain filling percentage was observed in Peizataifeng and Huayou 213 and reduced grain number per panicle in E3. Additionally, both E1 and E6 had $42.77 \%$ and $41.93 \%$ higher harvest index, respectively as compared to other environments. Among rice varieties, the highest harvest index was recorded in the following order: Huahang $31(53.02 \%)>$ Yuxiangyouzhan (40.08\%) > Peizataifeng (36.28\%) > Huayou 213 (34.93\%) (Fig. 3c).
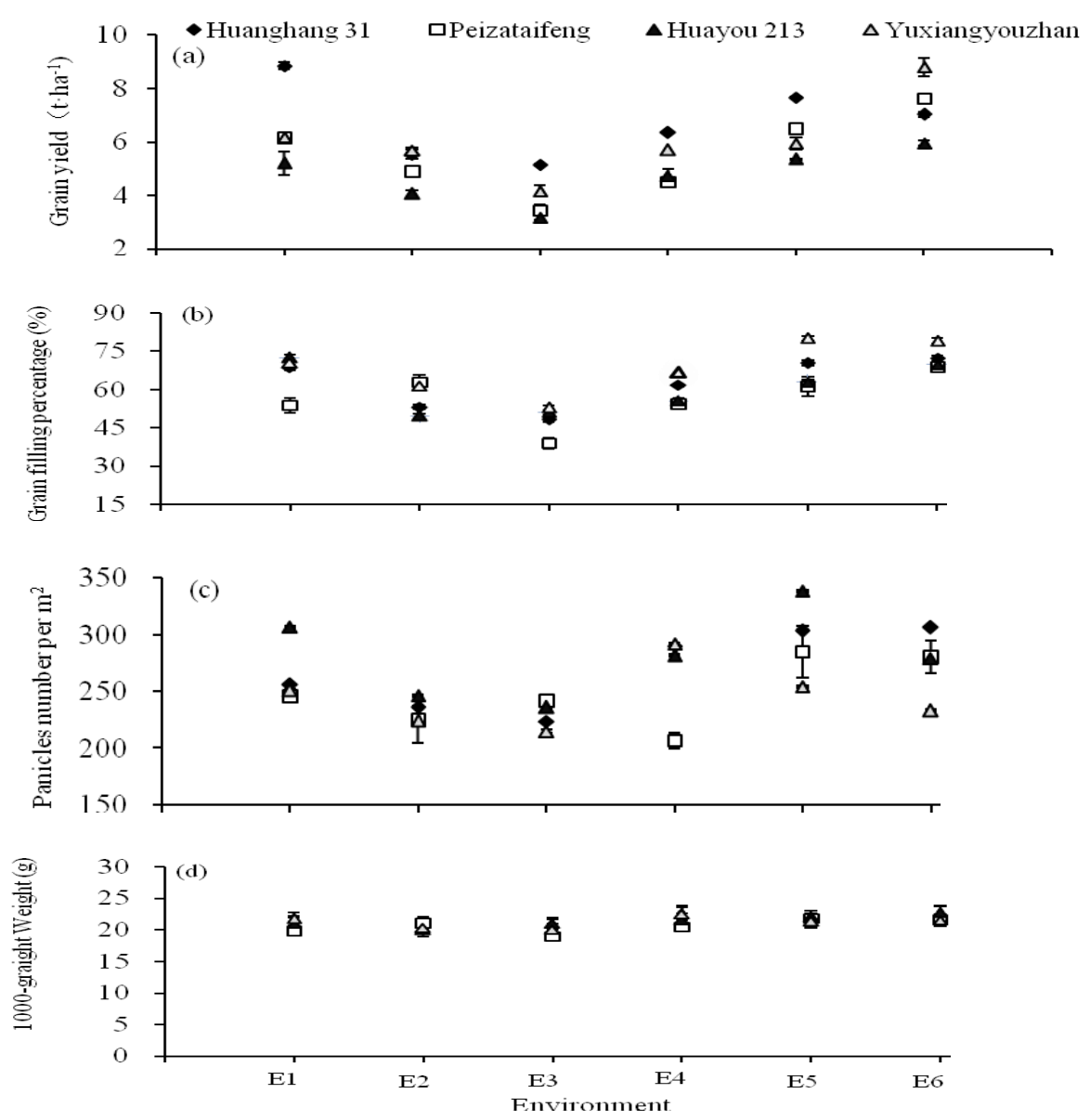

Figure 2. Effect of series of six different environments on (a) grain yield $\left(t h a^{-1}\right),(b)$ grain filling \%, (c) panicles number per $\mathrm{m}^{2}$, (d) 1000-grain weight ( $\mathrm{g}$ ) of four different rice cultivars. Capped bars indicate means of three replicates $\pm S E$. 

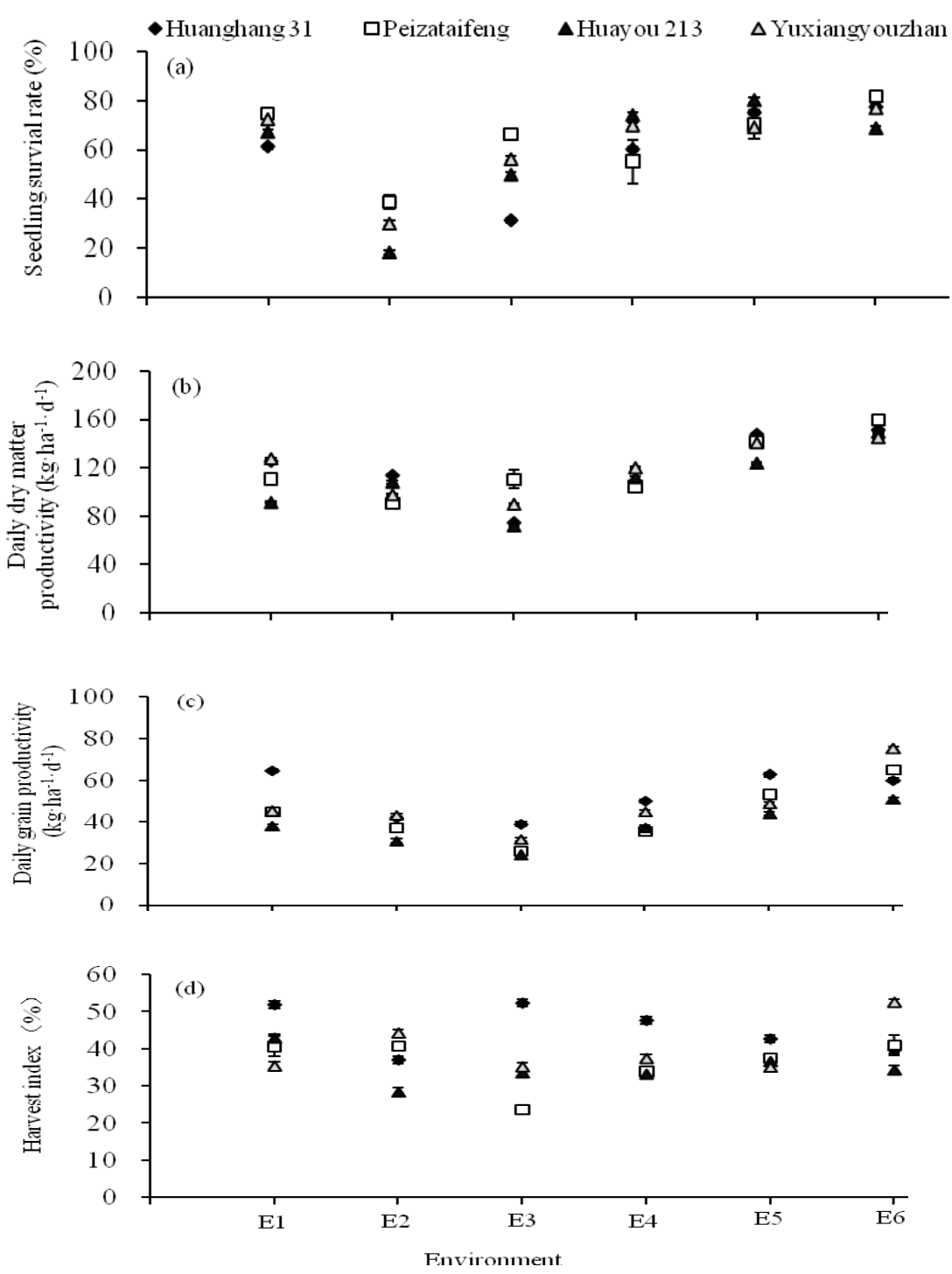

Figure 3. Effect of series of 6 different environments on (a) seedling survival rate (\%), (b) daily dry matter productivity ( $\left.\mathrm{kg} \mathrm{ha}^{-1} \mathrm{~d}^{-1}\right)$, (c) harvest index (\%), (d) daily grain productivity ( $\mathrm{kg} \mathrm{ha}^{-1}$ $\left.d^{-1}\right)$ of four different rice cultivars. Capped bars indicate means of three replicates $\pm S E$.

Correlation analysis depicted that grain yield significantly and positively correlated with filled grain $\%(\mathrm{r}=0.722), 1000$-grain weight $(\mathrm{r}=0.478)$, daily grain productivity $(\mathrm{r}$ $=0.978)$, dry matter accumulation $(r=0.718)$, harvest index $(r=0.692)$ and daily dry matter productivity $(r=0.703)$, however, panicles $\mathrm{m}^{-2}$ and grains panicle ${ }^{-1}$ were remained non-significant regarding grain yield $(r=0.303$ and $r=0.115)$, respectively. Furthermore, panicles $\mathrm{m}^{-2}$ was negatively correlated with grain panicle ${ }^{-1}$ while grains panicle $^{-1}$ also showed a negative correlation with filled grain \%, 1000-grain weight, dry matter accumulation and daily dry matter productivity (Table 3). 
Table 3. Correlation analyses for seedling survival rate, grain yield, yield related traits and productivity of rice among varieties and treatments

\begin{tabular}{|c|c|c|c|c|c|c|c|c|c|}
\hline Traits & Grain yield & $\begin{array}{l}\text { Panicles } \\
\text { number per } \\
\mathrm{m}^{2}\end{array}$ & $\begin{array}{l}\text { Grains per } \\
\text { panicle }\end{array}$ & $\begin{array}{l}\text { Filled grain } \\
\text { percentage }\end{array}$ & $\begin{array}{l}\text { 1000-grain } \\
\text { weight }\end{array}$ & $\begin{array}{l}\text { Daily grain } \\
\text { productivity }\end{array}$ & $\begin{array}{l}\text { Dry matter } \\
\text { accumulation }\end{array}$ & $\begin{array}{l}\text { Harvest } \\
\text { index }\end{array}$ & $\begin{array}{l}\text { Daily dry matter } \\
\text { productivity }\end{array}$ \\
\hline Grain yield & 1 & & & & & & & & \\
\hline $\begin{array}{l}\text { Panicles number } \\
\text { per } \mathrm{m}^{2}\end{array}$ & 0.303 & 1 & & & & & & & \\
\hline $\begin{array}{l}\text { Number of grains } \\
\text { per panicle }\end{array}$ & 0.115 & $0.561 * *$ & 1 & & & & & & \\
\hline $\begin{array}{ll}\text { Filled } & \text { grain } \\
\text { percentage } & \end{array}$ & $0.722 * *$ & $0.425^{*}$ & -0.128 & 1 & & & & & \\
\hline 1000-grain weight & $0.478^{*}$ & $0.649 * *$ & -0.365 & $0.641 * *$ & 1 & & & & \\
\hline $\begin{array}{ll}\text { Daily } & \text { grain } \\
\text { productivity } & \end{array}$ & $0.978 * *$ & 0.351 & 0.069 & $0.746 * *$ & $0.542 * *$ & 1 & & & \\
\hline $\begin{array}{l}\text { Dry matter } \\
\text { accumulation }\end{array}$ & $0.718 * *$ & $0.450 *$ & -0.013 & $0.604 * *$ & $0.424 *$ & $0.753 * *$ & 1 & & \\
\hline Harvest index & $0.692 * *$ & 0.019 & 0.191 & $0.431 *$ & 0.285 & $0.627 * *$ & 0.009 & 1 & \\
\hline $\begin{array}{l}\text { Daily dry matter } \\
\text { productivity }\end{array}$ & $0.703 * *$ & $0.485^{*}$ & -0.064 & $0.633 * *$ & $0.510 *$ & $0.784 * *$ & $0.969 * *$ & 0.023 & 1 \\
\hline
\end{tabular}

*Significant at $\mathrm{p} \leq 0.05 ; * *$ Significant at $\mathrm{p} \leq 0.01$; values without asterisks are non-significant at both $\mathrm{p} \leq 0.01 ; \mathrm{p} \leq 0.05$ 


\section{Discussion}

Enhancing grain yield has long been a main purpose of rice researchers to meet the needs of increasing population; however climate change threatens to decrease the crop productivity. In the process of rice yield formation, rice growth period is confronted with different light and temperature conditions. Differences in sowing dates might result in changed growth periods thereby affecting plant biomass accumulation through altering the length of photosynthetic time (Yao et al., 2012). Thus, sowing dates affect grain yield by influencing the whole rice growing process. Sowing or planting dates for crops like rice, wheat, maize etc. were studied worldwide in coping with global climate change or for gaining high yield and quality (Sacks et al., 2010; Yao et al., 2011; Hussain et al., 2012). Sowing dates significantly affected the seedling survival rate, grain yield, yield related traits and rice productivity of plants growing in different environments (Table 2). Similarly, Sun et al. (2012) reported a significant effect of sowing dates on yield and some yield related traits (spikelets and seed setting rate) under low-light stress at heading stage. E1 and E6 supposed to increase yield due to increase in panicle number per $\mathrm{m}^{2}$, fully filled grain percentage and 1000-grain weight, yet different rice varieties performed differently in this connection (Fig. 2).

Grain yield productivity on each sowing date (E1 to E6) was $48.14 \mathrm{~kg} \mathrm{ha}^{-1} \mathrm{~d}^{-1}$, $38.21 \mathrm{~kg} \mathrm{ha}^{-1} \mathrm{~d}^{-1}, 30.14 \mathrm{~kg} \mathrm{ha}^{-1} \mathrm{~d}^{-1}, 41.86 \mathrm{~kg} \mathrm{ha}^{-1} \mathrm{~d}^{-1}, 52.16 \mathrm{~kg} \mathrm{ha}^{-1} \mathrm{~d}^{-1}$ and $62.80 \mathrm{~kg} \mathrm{ha}^{-1}$ $\mathrm{d}^{-1}$, respectively (Fig. 3d). Thus, an increase in rice yield by more than $30.14 \mathrm{~kg} \mathrm{ha}^{-1} \mathrm{~d}^{-1}$ for each day may be achieved, if rice sowing was earlier before and after E3. Rice sown on both E2 and E3 had a lower seedling survival rate due to extensive low temperature which caused a gradual reduction in panicle number per $\mathrm{m}^{2}$ (Fig. 2c). Higher grain filling percentage and 1000-grain weight was observed on rice sown earlier before E3 and might be due to prolonged rice photosynthesis time in early sowing and warmer climate in late sowing enjoyed by crop resulting in higher daily dry matter productivity. Under delayed sowing, rice spikelet number per panicle and fully filled grain percentage decreased, and no difference in panicle and grain weight was noticed (Yao et al., 2010, 2011; Huo et al., 2012; Abid et al., 2015). Shorter rice photosynthesis time and higher temperature at panicle initiation stage might be the possible reasons for the fewer grain number per panicle, observed in late sowing environment (E4-E6). These findings corroborate with Chen et al. (2003) who argued that in single-season rice, delayed sowing reduced the grain number per panicle, but increased seed setting rate and 1000-grain weight, improved late leaf area index, increased photosynthetic products and improved rice quality. In Philippines, Peng et al. (2004) observed 10\% reduction in paddy yield for each unit rise in minimum temperature limits during one-season of rice cultivation whereas rice yield variability and poor seed quality due to extreme temperatures at reproductive stage was also reported by Martínezeixarch and Eills (2015).

All rice cultivars were remained significantly different for seedling survival rate, grain yield, and yield related traits and rice productivity (Table 2). Variation in grain 
yield and other parameters for different rice genotypes might be due to their genetic diversity and morphological characters (Yang et al., 2007; Shahidullah et al., 2009; Ashfaq et al., 2012). Higher grain yield recorded in rice variety Huahang 31 (6.75 $\left.\mathrm{t} \mathrm{ha}^{-1}\right)$ might be attributed to higher yield related traits (panicle number per $\mathrm{m}^{2}$ and 1000-grain weight) (Fig. 2), daily dry matter productivity and harvest index (Fig. $3 b$ and c). Yuxiangyouzhan had a higher grain number per panicle, grain filling percentage and daily dry matter productivity, but reduced panicles per $\mathrm{m}^{2}$, 1000-grain weight and harvest index led to lower grain yield than Huanghang 31. The lowest grain yield was noted in Huayou 213 due to the reduction in yield related traits (except panicles per $\mathrm{m}^{2}$ ), daily dry matter productivity and harvested index (Fig. 2 and 3).

$\mathrm{E} \times \mathrm{V}$ interaction had significant effect on rice yield, yield related traits and other parameters (Table 1). Huahang 31 and Yuxiangyouzhan (sown on $24^{\text {th }}$ February and $20^{\text {th }}$ March, respectively) provided higher grain yield that might be due to higher dry matter productivity and harvest index in both these cultivars (Fig. 2 and 3). The substantial decrease in grain filling percentage observed in Peizataifeng and Huayou 213 in E3 (sown on March 5) and along with reduced grain number per panicle observed in Huayou 213 in E3 (sown on March 5) resulted in minimum grain yield in both these cultivars. Genetic variations among rice varieties might also be responsible for differential response regarding grain yield, dry matter accumulation and harvest index under the same or different environmental conditions (Yao et al., 2010). For instance, delayed sowing resulted in yield decline due to reduced spikelet number per panicle and seed setting rate, but degree of yield reduction was different among different rice varieties (Nagarajan et al., 2010). Similarly, differential yield response and environmental sensitivity of different rice cultivars under different environments was also reported by Wang et al. (2001). We further found that different rice varieties produced different yields for $\mathrm{E} \times \mathrm{V}$ interaction which indicates a strong relationship among local climatic conditions including temperature fluctuations, photosynthetic and respiratory activities of plants and yield formation and other morpho-physiological and biochemical mechanisms that affect growth and productivity of rice.

\section{Conclusion}

Conclusively, among all environments, only E3 caused yield reduction by $30.14 \mathrm{~kg}$ $\mathrm{ha}^{-1} \mathrm{~d}^{-1}$. Compared to other environments, the grain yield declined by $14.45-45.86 \%$ in E3, however, different rice varieties performed differently in this regard. Hence, the entire environment was considered favorable for rice production in Guangdong province (China) except for E3.

Acknowledgements. Agricultural research projects in Guangdong Province (2004B20101007) and Guangdong Province production and research subproject (2011AO20202001), China. 


\section{REFERENCES}

[1] Abid, M., Khan, I., Mahmood, F., Ashraf, U., Imran, M., Anjum, S.A. (2015): Response of hybrid rice to various transplanting dates and nitrogen application rates. - Philippine Agricultural Scientist 98: 98-104.

[2] Ashraf, U., Anjum, S.A., Ehsanullah, Khan, I., Tanveer, M. (2014): Planting geometryinduced alteration in weed infestation, growth and yield of puddled rice. - Pakistan Journal of Weed Science Research 20(1): 77-89.

[3] Ashraf, U., Kanu, A. S., Mo, Z., Hussain, S., Anjum, S. A., Khan, I., Abbas, R.N., Tang, $X$. (2015): Lead toxicity in rice: effects, mechanisms, and mitigation strategies - a mini review. - Environmental Science and Pollution Research 22(23): 18318-18332. doi: 10.1007/s11356-015-5463-x

[4] Ashraq, M., Khan, A.S., Khan, S.H.U., Ahmad, R. (2012): Association of various morphological traits with yield and genetic divergence in rice (Oryza sativa). International Journal of Agriculture \& Biology 14(1): 55-62.

[5] Carriger, S., Vallee, D. (2007): More crop per drop. - Rice Today 6: 10-13.

[6] Chen, J.L., Lu, F.Z., Zhou, J.P., Pang, X., Lu, X.Z., Xu, Y.X. (2003): Effect of different sowing dates but same transplanting time on the growth and development of japonica Changyou 1. - Jiangsu Journal of Agricultural Science (5): 29-30 (in Chinese with English abstract).

[7] Chen, X.G., Wang, H., Zou, Y.C., Lin, Q.S., Cai, L. (2010): Adaptation and determination of sowing date under climate change in early matured rice in Guangdong Province. - Acta Ecologica Sinica 30(17): 4748- 4755 (in Chinese with English abstract).

[8] Chen, J.L., Lu, F.Z., Zhou, J.P., Pang, X., Lu, X.Z., Xu, Y.X. (2003): Effect of different sowing dates but same transplanting time on the growth and development of japonica Changyou 1. - Jiangsu Journal Agricultural Science 5: 29-30 (in Chinese with English abstract).

[9] Ehsanullah, Anjum, S.A., Ashraf, U., Rafiq, H., Tanveer, M., Khan, I. (2014): Effect of sowing dates and weed control methods on weed infestation, growth and yield of directseeded rice. - Philippine Agricultural Scientist 97: 307-312.

[10] Farooq, M., Siddique, K.H.M., Rehman, H., Aziz, T., Lee, D.J., Wahid, A. (2011): Rice direct seeding: Experiences, challenges and opportunities. - Soil \& Tillage Research 111: 87-98. doi:10.1016/j.still.2010.10.008

[11] Fang, F.P., Cheng, S.H. (2009): Rice production capacity in China. Chinese Journal of Rice Science 23(6): 559-566 (in Chinese with English Abstract).

[12] Huang, Z.Z., Wang, H., Chen, X.G., Ye, W.D. (2011): Characteristics of "Dragon Boat Water" and its impact on the early rice yield under climate change. - Ecology and Environmental Science 20(5): 793-797 (in Chinese with English Abstract).

[13] Huo, Z.Y., Yao, Y., Zhang, H.C., Xai, Y., Ni, X.C., Dai, Q.G., Xu, K., Wei, H.Y. (2012): Differences of nitrogen absorption and utilization efficiency in direct seeding rice with different sowing date. - Journal of Yangzhou University 33(4): 39-45 (in Chinese with English Abstract).

[14] Hussain, M., Farooq, M., Shabir, G., Khan, M.B., Zia, A.B. (2012). Delay in planting decreases wheat productivity. - International Journal of Agriculture \& Biology 14(4): 533-539.

[15] [IPCC] Intergovernmental Panel on Climate Change. (2007): Mitigation for Climate Chnage.- In: Metz, B., Davidson, O.R., Bosch, P.R., Dave, R., Meyer L.A. (eds.) Contribution of Working Group III to the Fourth Assessment Report of the Intergovernmental Panel on Climate Change, 2007. Cambridge University Press, Cambridge, UK and New York. 
[16] Kargbo, M. B., Shenggang, P., Zhaowen, M., Zaiman, W., Xiwen, L., Hua, T., Hossain, M.F., Ru, T.X. (2016): Physiological basis of improved performance of super rice (Oryza sativa L.) to deep placed fertilizer with precision hill-drilling machine. International Journal of Agriculture \& Biology 18: 797-804. doi: 10.17957/IJAB/15.0173

[17] Krishnan, P., Ramakrishnan, B., Reddy, K.R., Reddy, V. (2011): High-temperature effects on rice growth, yield, and grain quality. - Advances in Agronomy 111: 87-206. doi: 10.1016/B978-0-12-387689-8.00004-7

[18] Li, M., Ashraf, U., Tian, H., Mo, Z.W., Pan, S.G., Anjum, S.A., Duan, M.Y., Tang, X.R. (2016): Manganese-induced regulations in growth, yield formation, quality characters, rice aroma and enzyme involved in 2-acetyl-1-pyrroline biosynthesis in fragrant rice. Plant Physiology and Biochemistry 103: 167-175. doi: http://dx.doi.org/ 10.1016/j.plaphy.2016.03.009

[19] Luo, X.W., Liu, T., Jiang, E.H., Li, Q. (2007): Design and experiment of hill sowing wheel of precision rice direct-seeder. - Transections of Chinese Society of Agricultural Engineering 23(3): 108-112 (in Chinese with English abstract).

[20] Luo, X.W., Jiang, E.H., Wang, Z.M., Tang, X.R., Li, J.H., Chen, W.T. (2008): Precision rice hill-drop drilling machine. - Transections of Chinese Society of Agricultural Engineering 24(12): $52-56$ (in Chinese with English abstract).

[21] Martínezeixarch, M., Elli, R.H. (2015): Temporal sensitivities of rice seed development from spikelet fertility to viable mature seed to extreme-temperature. - Crop Science 55: 354-364. doi: 10.2135/cropsci2014.01.0042

[22] Mo, Z.W., Ashraf, U., Pan, S.G., Kanu, A.S., Li, W., Duan, M.Y., Tian, H., Tang, X.R. (2016a): Exogenous application of plant growth regulators induce chilling tolerance in direct seeded super and non-super rice seedlings through modulations in morphophysiological attributes. - Cereal Research Communications 44(3): 524-534. doi: 10.1556/0806.44.2016.010

[23] Mo, Z., Huang, J., Xiao, D., Ashraf, U., Duan, M., Pan, S., Tian, H., Xiao, L., Zhong, K., Tang, X. (2016b): Supplementation of 2-Ap, Zn and La improves 2-acetyl-1pyrroline concentrations in detached aromatic rice panicles in vitro. - PLoS ONE 11: e0149523. doi: 10.1371/journal.pone.0149523

[24] Nagarajan, S., Jagadish, S.V.K., Prasad, A.S.H., Thomar, A.K., Anand, A., Pal, M., Agarwal, P.K. (2010): Local climate affects growth, yield and grain quality of aromatic and non-aromatic rice in northwestern India. - Agriculture, Ecosystem \& Environment 138: 274-281. doi:10.1016/j.agee.2010.05.012

[25] Peng, S.B., Tang, Q.Y., Zou, Y.B. (2009): Current status and challenges of rice production in China. - Plant Production Science 2(1):3-8. doi.org/10.1626/pps.12.3

[26] Peng, S.B., Huang, J.L., Sheehy, J.E., Laza, R.C., Visperas, R.M., Zhong, X.H., Centeno, G.S., Khush, G.S., Cassman, K.G. (2004): Rice yields decline with higher night temperature from global warming. - Proceedings of the National Academy of Sciences USA 101: 9971-9975.

[27] Sacks, W.J., Deryng, D., Foley, J.A., Ramankutty, N. (2010): Crop planting dates: an analysis of global patterns. - Global Ecology and Biogeography 19(5): 607-620. doi: 10.1111/j.1466-8238.2010.00551.x

[28] Shahidullah, S.M., Hanafi, M.M., Ashrafuzzaman, M., Ismail, M.R., Salam, M.A. (2009): Phenological characters and genetic divergence in aromatic rices. - African Journal of Biotechnology 8: 3199-3207.

[29] Sun, Y.Y., Sun, Y.J., Chen, L., Xu, H., Ma, J. (2012): Effects of different sowing dates and low-light stress at heading stage on the physiological characteristics and grain yield of hybrid rice. - Chinese Journal of Applied Ecology 23(10): 2737-2744. 
[30] Tang, X.R., Luo, X.W., Li, G.X., Wang, Z.M., Zheng, T.X., Chen, W.T., Shu, S.F. (2009): Yield formation characteristics of precision hill-drop drilling early rice. Transactions of the Chinese Society of Agricultural Engineering 25(7): $84-87$ (in Chinese with English abstract).

[31] Takai, T., Matsuura, S., Nishio, T., Ohsumi, A., Shiraiwa, T., Horie, T. (2006): Rice yield potential is closely related to crop growth rate during late reproductive period. Field Crops Research 96: 328-335. doi:10.1016/j.fcr.2005.08.001

[32] Wang, F.Y., Zhang, H.C., Zhao, X.H., Duan, X.M., Ding, Y.F., Huang, P.S., Lu, G.R., Wang, G.Q. (2001): Study on the effects of temperature and illumination on grade of filled grain in rice. - Scientia Agricultura Sinica 34(4): 396-402 (in Chinese with English abstract).

[33] Wang, H., Du, Y.D., Chen, X.G., Zhai, Z.H. (2012): Suitable temperature index for early rice high yield in Guangdong Province of South China. - Chinese Journal of Ecology 31(3): 594-599 (in Chinese with English abstract).

[34] Wang, H., Chen, X.G., Huang, Z.Z. (2011): Variations of meteorological disasters on early rice production in Guangdong province under climate change. - Journal of Tropical Meteorology 27(6): 937-941 (in Chinese with English abstract).

[35] Yang, W., Peng, S., Laza, R.C., Visperas, R.M., Sese, M.L.D. (2007): Grain yield and yield attributes of new plant type and hybrid rice. - Crop Science 47: 1393-140. doi:10.2135/cropsci2006.07.0457

[36] Yao, Y., Huo, Z.Y., Zhang, H.C., Xia, Y., Ni, X.C., Dai, Q.G., Xu, K., Wei, H.Y., Xiao, Y. C., Wang, X. (2011): Effects of sowing date on yield and quality of direct seeding rice of different types and varieties. - China Agricultural Science 44(15): 3098-3107. (in Chinese )

[37] Yao, Y., Huo, Z.Y., Zhang, H.C., Xia, Y., Ni, X.C., Dai, Q.G., Xu, K., Wei, H.Y. (2012): Effects of sowing date on growth stage and utilization of temperature and illumination of direct seeding rice in different ecological regions. - Scientia Agricultura Sinica 45(4): 633-647. (in Chinese with English abstract)

[38] Yao, Y., Huo, Z.Y., Zhang, H.C., Xia, Y., Ni, X.C., Dai, Q.G., Xu, K., Wei, H.Y. (2010): Effects of sowing date on the growth characteristics of direct seeding rice. Chinese Journal of Ecology 29(11): 2131-2138. (in Chinese with English abstract)

[39] Yi, Z.X., Tu, N.M., Tan, W.X., Zhou, J.P. (2010): Investigate of the application of direct seeding rice in Hunan. - Crop Research 24(4):327-329. (in Chinese with English abstract).

[40] Zhang, X.F., Wang, D.Y., Fang, F.P., Zhen, Y.K., Liao, X.Y. (2005): Food safety and rice production in China. - Research of Agricultural Modernization 26(2): 85-88 (in Chinese with English abstract). 